\title{
A New Recycling Process for Tungsten Carbide Soft Scrap That Employs a Mechanochemical Reaction with Sodium Hydroxide
}

\author{
Jaeryeong Lee *, Suyun Kim and Byoungjin Kim \\ Department of Energy \& Resources Engineering, Kangwon National University, Chuncheon 24341, Korea; \\ syoon0270@kangwon.ac.kr (S.K.); iybj90@kangwon.ac.kr (B.K.) \\ * Correspondence: jr-lee@kangwon.ac.kr; Tel.: +82-33-250-6252
}

Received: 2 June 2017; Accepted: 19 June 2017; Published: 22 June 2017

\begin{abstract}
WC soft scrap, including Co used as a binder, thermally oxidized at $600{ }^{\circ} \mathrm{C}$, was subjected to grinding with $\mathrm{NaOH}$ in a mechanochemical reaction, followed by water leaching to establish an effective recycling process. $\mathrm{Na}_{2} \mathrm{WO}_{4}$ was synthesized through a mechanochemical (MC) reaction with oxidized scrap, and $\mathrm{Na}_{2} \mathrm{CO}_{3}$ was formed when the mixing ratio of $\mathrm{NaOH}$ increased. These as-synthesized compounds were water-soluble. When the weight ratio of soft scrap to $\mathrm{NaOH}$ was 1:0.5, 99.2\% W was extracted by water leaching, while the extraction yield of Co was limited to $3.57 \%$ under the same conditions.
\end{abstract}

Keywords: WC soft scrap; thermal oxidation; mechanochemical reaction; sodium hydroxide; water leaching

\section{Introduction}

Tungsten is one of the most important refractory metals, and tungsten carbide (WC) is used in a variety of products, such as cutting tools, wear parts, and mining drill bits, because of its superior toughness and hardness. Moreover, other refractory carbides, such as $\mathrm{TiC}$ and $\mathrm{TaC}$, are frequently combined with WC alloys along with a metal binder or cementing agent, typically cobalt (Co), which holds the hard carbide grains together in a dense composite structure. In this regard, sustainable hard metal production is important to and supports modern industry, especially as it expands with global population growth and elevating standards of living. Concurrently, it is important to reduce the environmental impact of industrial processes because emission remediation costs have escalated; some harmful processes have been completely outlawed. The majority of tungsten $(\mathrm{W})$ produced is used to meet the demand for hard metals, so it is critical to consider the W supply chain. Over the past decade, $\mathrm{W}$ precursor prices have undergone a dramatic escalation (an eight-fold increase) and industrial electricity costs (a major production expense) have increased significantly (by $30 \%$ ). In this regard, $\mathrm{W}$ production via the recycling of hard-metal scrap, which allows for reduced cost, energy consumption, and environmental impact, has been in the limelight. The recycling ratio of $\mathrm{W}$ has increased continuously, but still is no greater than approximately $25 \%$ due to the physical and chemical diversity of various types of scrap (e.g., materials that have reached the end of their life or more prevalently those that are generated during the manufacturing of $\mathrm{W}$ materials (including WC)). This scrap can be classified by shape; (1) powder (soft scrap) or (2) bulky (hard scrap) [1-10].

Worn tools, such as cutting and drilling bits made of WC hard metals, are generally classified as hard scrap. Soft scrap does not have a defined shape and is composed mainly of unsintered WC powder. Typically, this scrap is the waste product of W manufacturing, and it includes wires, coils, powders, and turnings. Soft scrap contains more metallic impurities than hard scrap, but does not need 
to be crushed like hard scrap. To enhance the recycling efficiency and increase the selective recovery of valuable metals, soft scrap should be treated with special care [11].

Researchers have investigated the recycling process of WC soft scrap via two main processes: alkali treatment and acid treatment [12-14]. Alkali treatment is typically executed in one of two ways: (1) transformation of WC to sodium tungstate, which is soluble in water, via an alkali fusion process using sodium nitrate/nitrite and sodium carbonate, or (2) dissolution of the oxidized scrap using a sodium hydroxide solution followed by the removal of impurities, the precipitation of tungstic acid, and dissolution by ammonia. In acid treatment, cobalt (which is utilized as a binder material) is extracted, first leaving an insoluble WC residue [15-18]. There are challenges to using both of these methods in an industrial process for recycling WC soft scrap. The alkali treatment requires a high-temperature fusion step and the separation of cobalt from the residue, which consume a large amount of energy. In the case of the acid treatment, the purity of the recovered WC is often too low for it to be reused as a raw material in hard metal manufacturing processes; high temperature alkali fusion processes or oxidation are needed to augment tungsten recovery $[19,20]$. In addition, the tungsten product may be contaminated by the incomplete leaching of cobalt. Moreover, after such treatments, $\mathrm{W}$ and Co must be recovered from the solution. For these reasons, we have developed a new process that involves a mechanochemical (MC) reaction and that enables us to recover tungsten selectively from oxidized soft scrap.

Here, we provide information and the optimal conditions that can be employed for the effective and economic recycling of WC soft scrap, enabling the facile recovery of tungsten.

\section{Experimental Procedure}

\subsection{Starting Materials and Characterization}

The soft scrap used in this study consisted of a hard metal sludge generated in the manufacturing process of turning tools composed of WC, and it was provided by TaeguTec Co., Daegu, Korea. This scrap contained not only the components generated as a byproduct in the manufacturing process, but also foreign substances, such as paper and organic dust, introduced during collection. To separate these substances, the scrap was screened with a \#500 sieve (aperture size: $25 \mu \mathrm{m}$ ) for $1 \mathrm{~h}$ using a sieve shaker (J-VSS, JISICO Co., Seoul, Korea). As a result, $77.33 \mathrm{wt} \%$ of the as-received scrap was acquired, and this portion was used as the starting material. The chemical composition of the starting materials was analyzed by X-ray fluorescence spectrometry (XRF, ZSX Primus II, Rigaku Co., Tokyo, Japan) (Table 1). The major elements detected were as follows: tungsten (W, $54.3 \mathrm{wt} \%)$, oxygen $(\mathrm{O}, 16.6 \mathrm{wt} \%)$, carbon (C, $15.7 \mathrm{wt} \%)$, cobalt (Co, $5.25 \mathrm{wt} \%$ ), silicon (Si, $1.95 \mathrm{wt} \%)$, and iron (Fe, $1.56 \mathrm{wt} \%)$. For the major components $(\mathrm{W}, \mathrm{Co})$ in the soft scrap, the leaching tendencies were surveyed, and a method to selectively recover $\mathrm{W}$ was presented.

Table 1. Chemical composition of the soft scrap used as a starting material in this study.

\begin{tabular}{cccc}
\hline Element & Content (wt \%) & Element & Content (wt \%) \\
\hline $\mathrm{W}$ & 54.3 & $\mathrm{Al}$ & 0.19 \\
$\mathrm{Co}$ & 5.25 & $\mathrm{Cu}$ & 0.07 \\
$\mathrm{Si}$ & 1.95 & $\mathrm{~V}$ & 0.05 \\
$\mathrm{Fe}$ & 1.56 & $\mathrm{Mo}$ & 0.05 \\
$\mathrm{Cr}$ & 0.28 & $\mathrm{C}$ & 15.7 \\
$\mathrm{Nb}$ & 0.24 & $\mathrm{O}$ & 16.6 \\
$\mathrm{Ni}$ & 0.23 & Others (B, Na, P, K) & 3.56 \\
\hline
\end{tabular}

\subsection{Experimental Procedure}

The recovery of $\mathrm{W}$ from the soft scrap proceeded in three steps: (1) thermal treatment to oxidize $\mathrm{WC}$, (2) MC treatment with $\mathrm{NaOH}$, and (3) water-leaching of the MC-treated scrap (Figure 1). 
The oxidation for the WC soft scrap should be carried out before the MC treatment because the WC powder, which is characterized by strength and hardness, may cause excessive abrasion of the grinding ports and media.

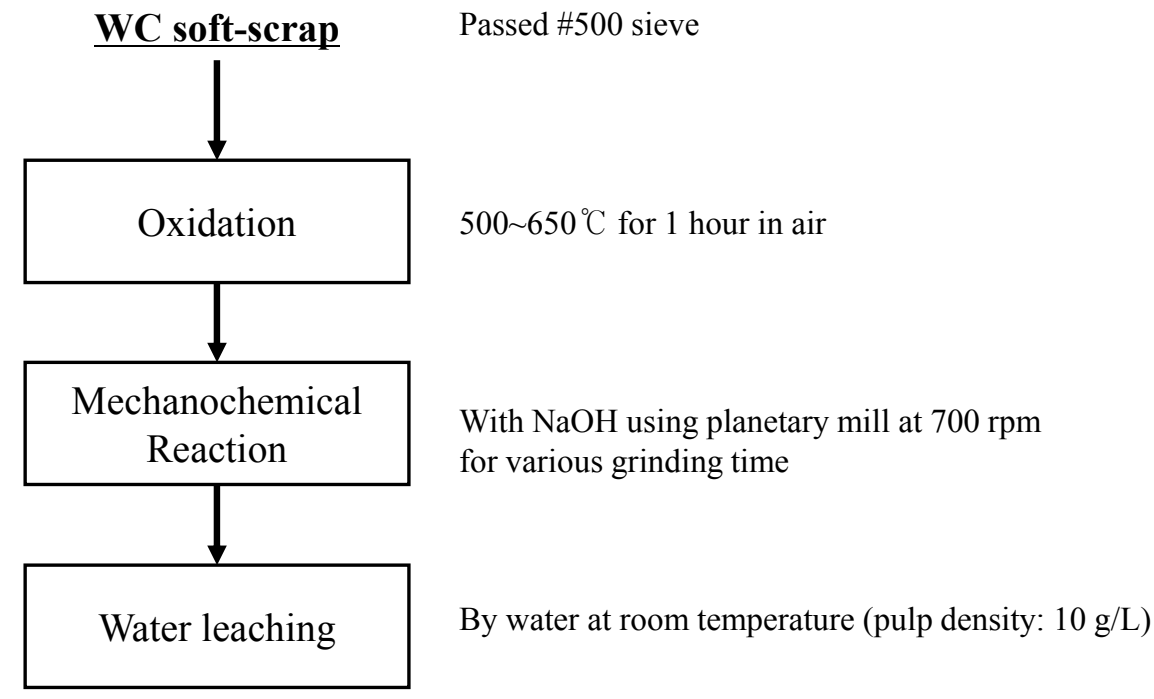

Figure 1. Flow chart of experimental procedures.

The starting material (WC soft scrap) was thermally oxidized using an electric furnace. The scrap (100 g) was placed in an alumina boat and heated for $1 \mathrm{~h}$ in air at temperatures ranging from 500 to $650^{\circ} \mathrm{C}$. Sodium hydroxide $(\mathrm{NaOH})$ was used as an additive to induce the $\mathrm{MC}$ reaction (Junsei Chemical Co., Ltd., Tokyo, Japan). The thermally treated scrap was mixed with sodium hydroxide $(\mathrm{NaOH})$ in different weight ratios (soft scrap: $\mathrm{NaOH}$ ), ranging from 1:0.3 to 1:0.5, and these mixtures were stored in a desiccator. A planetary mill (Pulverisette-7, Fritsch Gmbh, Idar-Oberstein, Germany) was used to grind the mixture for the MC reaction. The mill contained a pair of pots composed of zirconia installed on a rotating disc driven by an electric motor. The mixture $(4 \mathrm{~g})$ was placed in the port $\left(45 \mathrm{~cm}^{3}\right.$ inner volume) with seven zirconia balls ( $15 \mathrm{~mm}$ in diameter) and ground in air at $700 \mathrm{rpm}$ for certain periods of time. Subsequently, the ground mixture was leached in distilled water under the following conditions: room temperature, $10 \mathrm{~g} / \mathrm{L}$ slurry density, and stirring with a magnetic bar. During the leaching procedure, $1 \mathrm{~mL}$ leaching liquor samples were taken between $5 \mathrm{~s}$ and $1 \mathrm{~h}$. To acquire more accurate data, the total content of the two components (W, Co) was calculated for each sample. For this reason, the content of the components $(\mathrm{W}, \mathrm{Co})$ in both the leached solution and leached residue was analyzed. To dissolve the residue completely, a chemical digestion method was used. The leachability was determined via the following equation:

$$
\text { Leachability of } M(\%)=\frac{M \operatorname{content}(\mathrm{A})}{M \text { content }(\mathrm{A})+M \text { content }(\mathrm{B})} \times 100
$$

where $M$ denotes the two components ( $\mathrm{W}, \mathrm{Co})$ in this study, $M$ content (A) is the $M$ mass calculated from the $M$ concentration in the leached solution, and $M$ content (B) represents the $M$ mass in the leached residue after complete dissolution.

\subsection{Characterization}

Thermogravimetric and differential thermal analysis (TG-DTA, DTG-60H, Shimadzu Co., Kyoto, Japan) using a heating rate of $10^{\circ} \mathrm{C} / \mathrm{min}$ in air flow $(100 \mathrm{~mL} / \mathrm{min})$ scanning from room temperature up to $800{ }^{\circ} \mathrm{C}$ was utilized to determine the optimal temperature for oxidizing the soft scrap. The starting soft scrap and the treated mixtures were characterized by high resolution X-ray diffraction (HRXRD, 
X'pert-Pro MPD, PANalytical, Almelo, The Netherlands) using $\mathrm{Cu}-\mathrm{K} \alpha$ radiation $(\lambda=1.5406 \AA$ ) to identify how the phases changed after thermal and MC treatment. The leachability of the two major components (W, Co) was measured using an inductively coupled plasma spectrometer (ICP, OPTIMA 7300DV, Perkin Elmer, Waltham, MA, USA).

\section{Results and Discussion}

\subsection{Oxidation of the Starting Sample, Soft Scrap Passed by \#500 Sieve}

Figure 2 shows the XRD pattern of the starting sample, which was passed through a \#500 sieve (aperture size: $25 \mu \mathrm{m}$ ). Despite the various elements comprising this scrap (Table 1), only two compositions, WC (JCPDs No. 73-0471) and $\mathrm{CoC}_{x}$ (JCPDs No. 44-0962), were observed in the pattern. Further, the main peaks were associated with WC and only a single weak peak associated with $\mathrm{CoC}_{x}$ was observed. Peaks corresponding to the other components were not detected, likely owing to their relatively smaller particle size $(\leq 25 \mu \mathrm{m})$ and lower crystallinity.

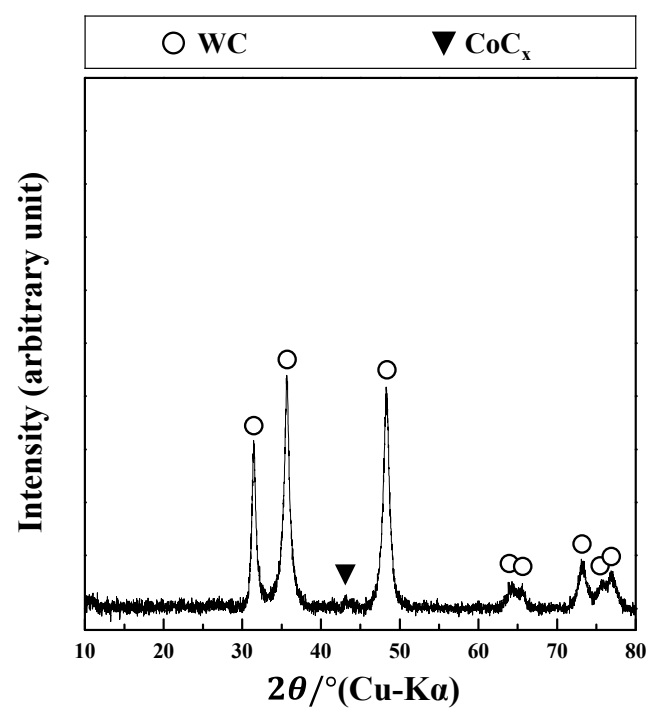

Figure 2. X-ray diffraction (XRD) pattern of the starting sample used in this study.

To determine the oxidation conditions for the samples, TG-DTA analysis was carried out (Figure 3). As shown in Figure 3a, the weight of the sample decreased by as much as $2.26 \%$ at approximately $320^{\circ} \mathrm{C}$. Then, it increased gradually with increasing temperatures up to $650{ }^{\circ} \mathrm{C}$ by as much as $14.87 \%$. As for the differential thermal analysis (Figure $3 b$ ), three exothermic peaks were observed at approximately 310 , 410 , and $570{ }^{\circ} \mathrm{C}$, corresponding to the combustion of the oil component in the sludge, the oxidation of cobalt carbide, and the oxidation of tungsten carbide, respectively (recovery of WC from hard material sludge). The weight loss observed via thermogravimetric analysis at temperatures lower than $318^{\circ} \mathrm{C}$ can be attributed to the removal of moisture and oil components; the weight gain observed between 320 and $650{ }^{\circ} \mathrm{C}$ can be attributed to the oxidation of WC-Co carbide. Thus, thermal treatment was carried out for $1 \mathrm{~h}$ between 500 and $650{ }^{\circ} \mathrm{C}$ to oxidize and eliminate the combustible impurities so that the optimal treatment temperature could be determined. XRD patterns of the thermally treated scrap are presented in Figure 4. When the scrap was treated at $500{ }^{\circ} \mathrm{C}$, the pattern of peaks was similar to that of the starting scrap (except the intensities differed). However, when the scrap was treated at $550{ }^{\circ} \mathrm{C}$, peaks corresponding to a new phase $\left(\mathrm{WO}_{3}\right.$ and $\left.\mathrm{CoWO}_{4}\right)$ were detected and their intensities increased with increasing treatment temperature. Peaks corresponding to the starting material were not observed when it was treated between 550 and $650{ }^{\circ} \mathrm{C}$, implying that the starting scrap should be treated thermally at $550{ }^{\circ} \mathrm{C}$ or higher (for $1 \mathrm{~h}$ in air) to be changed from a mixture of WC and $\mathrm{CoC}_{x}$ into a mixture of $\mathrm{WO}_{3}$ and $\mathrm{CoWO}_{4}$ phases. 

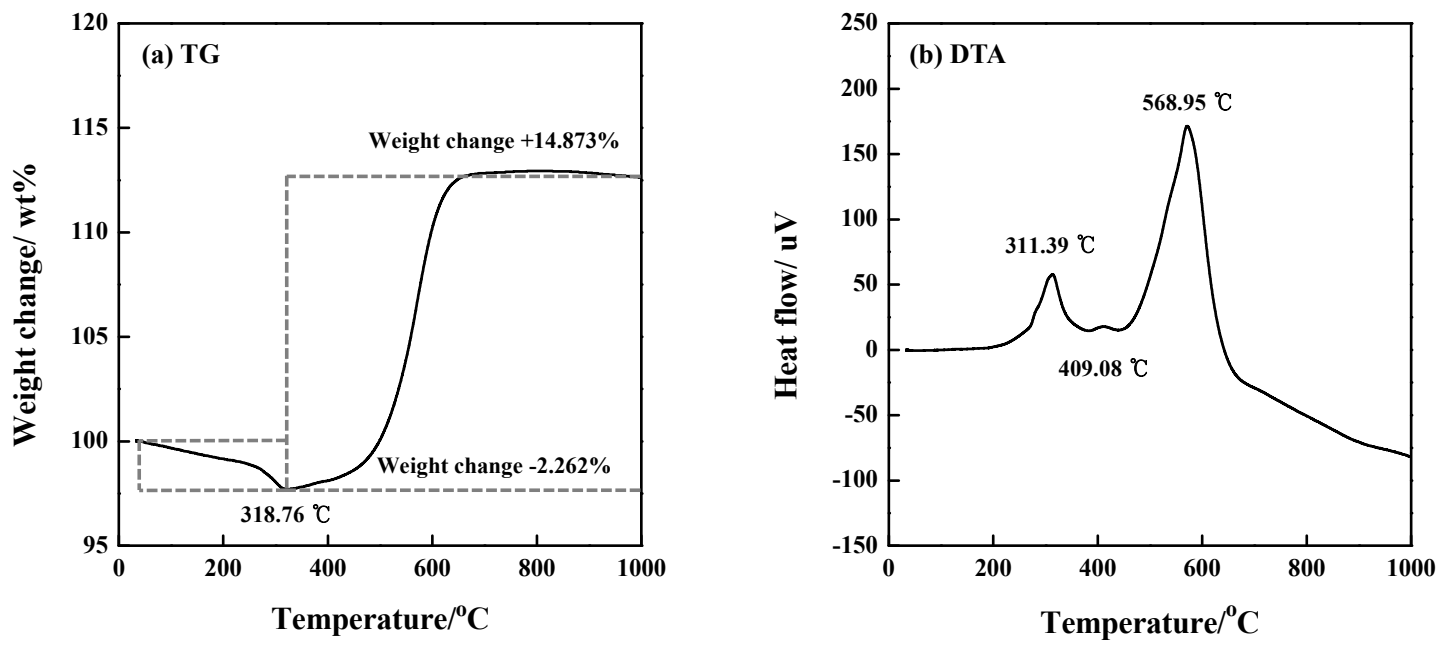

Figure 3. TG-DTA (thermogravimetric and differential thermal analysis) profiles for the soft scrap of WC.

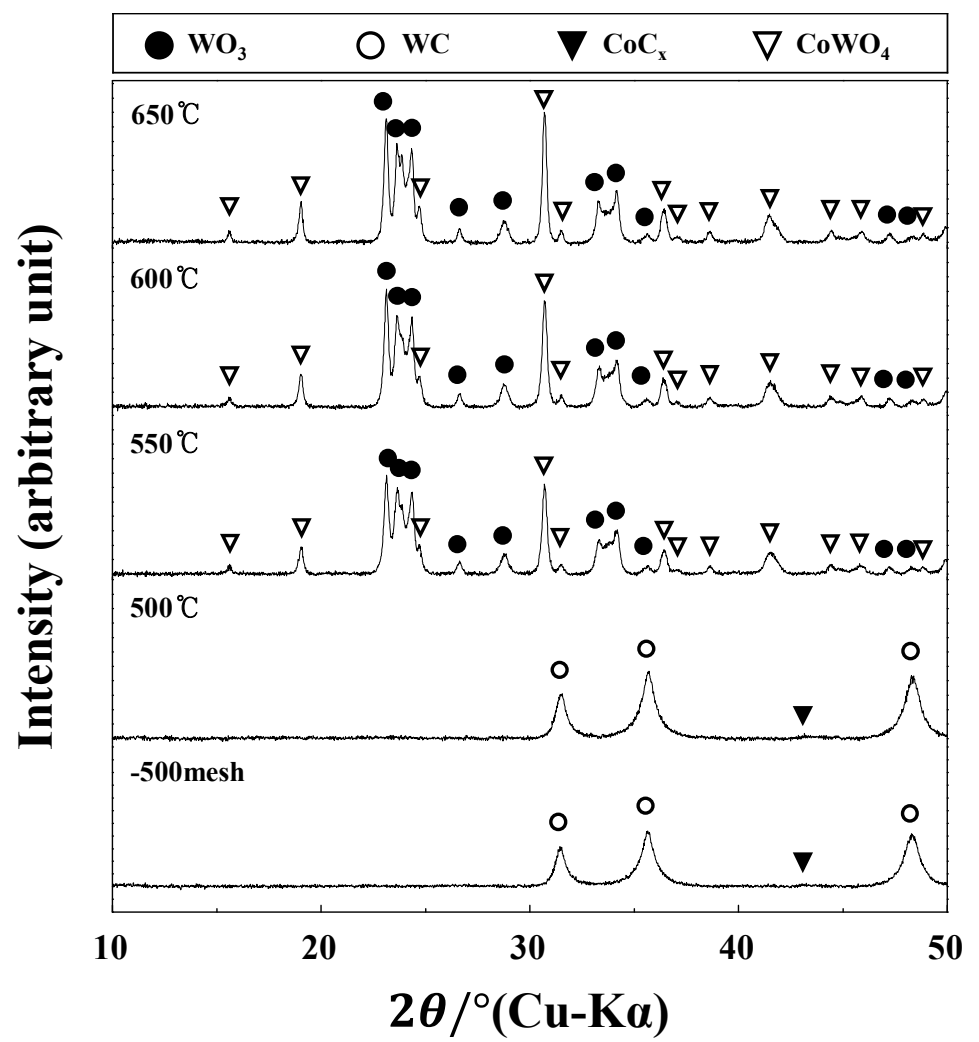

Figure 4. XRD pattern of the samples treated thermally from 500 to $650{ }^{\circ} \mathrm{C}$ for $1 \mathrm{~h}$ in air.

\subsection{Reaction of the Oxidized Scrap with $\mathrm{NaOH}$}

Scrap samples treated at 550,600 , and $650{ }^{\circ} \mathrm{C}$ were ground with $\mathrm{NaOH}$ to induce an $\mathrm{MC}$ reaction. Each of these scraps was mixed with $\mathrm{NaOH}$ at a weight ratio of 1:0.4. Four grams of the mixture was ground at $700 \mathrm{rpm}$ for $2 \mathrm{~h}$. After grinding, these mixtures were dried at $105^{\circ} \mathrm{C}$ for $2 \mathrm{~h}$ to eliminate moisture so that they could be analyzed using XRD.

The XRD patterns of the ground mixtures are shown in Figure 5. Peaks corresponding to $\mathrm{WO}_{3}$ and $\mathrm{CoWO}_{4}$ could not be found, and those of sodium tungsten oxide $\left(\mathrm{Na}_{2} \mathrm{WO}_{4}\right)$ were seen regardless of treatment temperature. However, a small WC peak was detected for the scrap treated at $550{ }^{\circ} \mathrm{C}$. 
These results imply that the oxide $\left(\mathrm{Na}_{2} \mathrm{WO}_{4}\right)$ shall be formed in the mechanochemical reaction as expressed by Equation (2).

$$
\mathrm{WO}_{3}+2 \mathrm{NaOH} \rightarrow \mathrm{Na}_{2} \mathrm{WO}_{4}+\mathrm{H}_{2} \mathrm{O}
$$

Moreover, the peak for WC was indicative of incomplete oxidation (Figure 5a). Therefore, an MC reaction and subsequent water-leaching should be carried out for the scrap treated at $600{ }^{\circ} \mathrm{C}$ or higher.

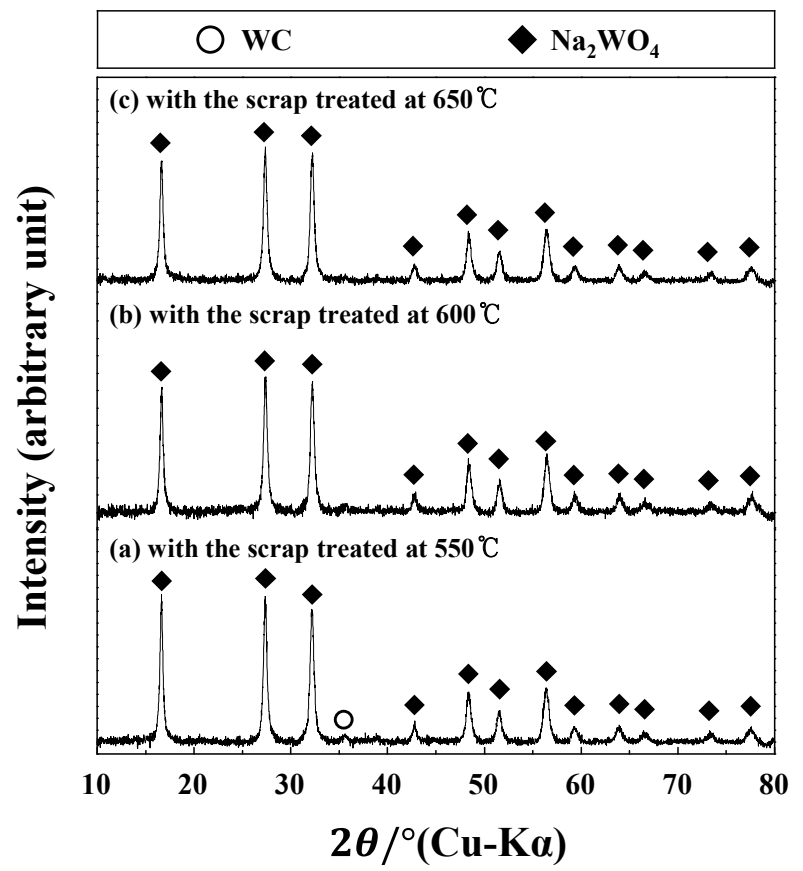

Figure 5. $\mathrm{XRD}$ patterns of the ground mixture, $\mathrm{NaOH}$, and the scrap thermally treated at (a) $550{ }^{\circ} \mathrm{C}$, (b) $600{ }^{\circ} \mathrm{C}$, and (c) $650{ }^{\circ} \mathrm{C}$.

For the scrap treated at $600{ }^{\circ} \mathrm{C}$, its $\mathrm{MC}$ reactivity was investigated under various grinding conditions (different mixing ratios (scrap: $\mathrm{NaOH}=1: 0.3-1: 0.5)$ and grinding times (5-30 min)). Figure 6(1) shows the XRD patterns of the scrap mixture treated at $600{ }^{\circ} \mathrm{C}$ with $\mathrm{NaOH}(1: 0.3)$ for various grinding times $(5,15$, and $30 \mathrm{~min})$. As shown in Figure 6(1-a), peaks corresponding to the unreacted scrap, such as $\mathrm{WO}_{3}$ (JCPDS No. 43-1035) and $\mathrm{CoWO}_{4}$, (JCPDS No. 72-0479), were observed. After 5 min of grinding, new peaks for $\mathrm{Na}_{2} \mathrm{WO}_{4}$ (JCPDS No. 70-1040) appeared. Upon increasing the grinding time, the intensities of these new peaks increased, while the intensities of the peaks corresponding to the unreacted compounds decreased gradually. For the scrap ground for 30 min (Figure 6(1-c)), only one $\mathrm{CoWO}_{4}$ peak was discernible, and the other peaks corresponded to $\mathrm{Na}_{2} \mathrm{WO}_{4}$. For the samples with a mixing ratio of 1:0.4 (Figure 6(2)), peaks corresponding to $\mathrm{Na}_{2} \mathrm{WO}_{4}$ were identified regardless of grinding time, and the changes in the intensities of those peaks were unperceivable. The peaks corresponding to $\mathrm{Na}_{2} \mathrm{CO}_{3}$ (JCPDS No. 77-2082) could be observed in the XRD pattern of the ground mixture with a ratio of 1:0.5 (Figure 6(3)). For the mixture ground for $5 \mathrm{~min}$ Figure 6(3-a), only peaks of $\mathrm{Na}_{2} \mathrm{WO}_{4}$ were found (similar to the pattern of Figure 6(2-a)), but with noticeable differences in their intensities. With increasing grinding time (15 min or longer), the peaks corresponding to $\mathrm{Na}_{2} \mathrm{WO}_{4}$ increased, and the peaks of $\mathrm{Na}_{2} \mathrm{CO}_{3}$ were also found. These results imply that the mixing ratio of $\mathrm{NaOH}$ dictates the $\mathrm{MC}$ reaction with the oxidized soft scrap, and the reactivity is improved with increasing $\mathrm{NaOH}$. For the mixing ratio of 1:0.3 (the lowest amount of $\mathrm{NaOH}$ used here), the MC reaction did not proceed until all of the scrap $\left(\mathrm{CoWO}_{4}\right)$ had reacted. These peaks corresponding to the unreacted scrap disappeared as the $\mathrm{NaOH}$ was increased through amorphization 
and $\mathrm{MC}$ reaction (Figure 6(2)). Moreover, $\mathrm{Na}_{2} \mathrm{CO}_{3}$ could be formed in the ground mixture (1:0.5) by the progressive reaction between residual carbide/carbonate components and $\mathrm{NaOH}$ (Figure 6(3)).

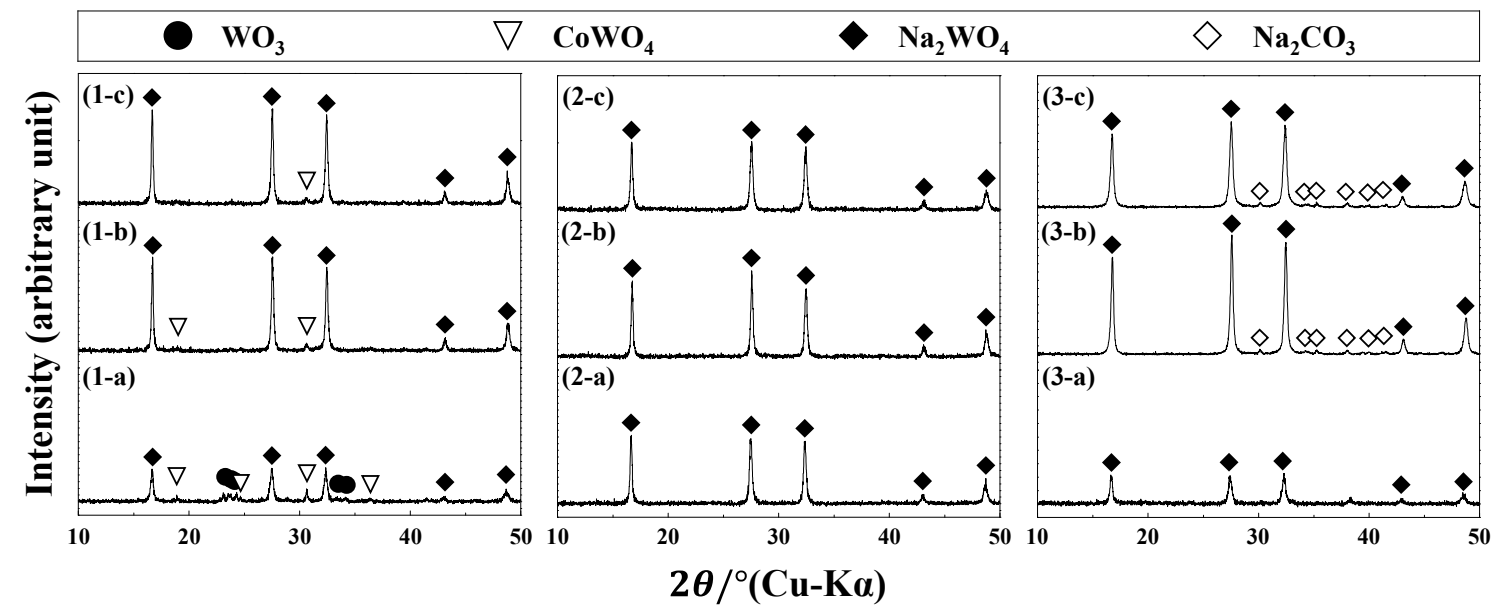

Figure 6. XRD patterns of the ground mixture: (1) mixing ratio of soft scrap: $\mathrm{NaOH}=1: 0.3$, (2) 1:0.4, (3) 1:0.5 with (a) grinding time: $5 \mathrm{~min}$, (b) $15 \mathrm{~min}$, and (c) $30 \mathrm{~min}$.

\subsection{Water-Leaching for the Ground Mixture of the Soft Scrap and $\mathrm{NaOH}$}

Figure 7 shows the leaching trends of $\mathrm{W}$ and Co according to the mixing ratio and grinding time. For the ground mixture with a ratio of 1:0.3 (Figure 7a), the leachability of $W$ increased proportionally with grinding time and its dissolution mostly stopped within $2 \mathrm{~min}$. Unusually, the extraction of $\mathrm{W}$ for the mixture ground for $5 \mathrm{~min}$ barely increased during $60 \mathrm{~min}$ of leaching. More $\mathrm{W}$ was extracted with the 1:0.4 (Figure $7 \mathrm{~b}$ ) mixture than with the 1:0.3 mixture, reaching a maximum of $98 \%$ within $60 \mathrm{~min}$. For the 1:0.5 (Figure 7c) mixture, the leachability of $\mathrm{W}$ was as high as $95 \%$ in the early stages of leaching (within $1 \mathrm{~min}$ ) and as much as $99.2 \%$ was extracted in less than $60 \mathrm{~min}$ of water-leaching. Co was difficult to extract, and its leachability was rarely more than $3.5 \%$ under any of the conditions explored.
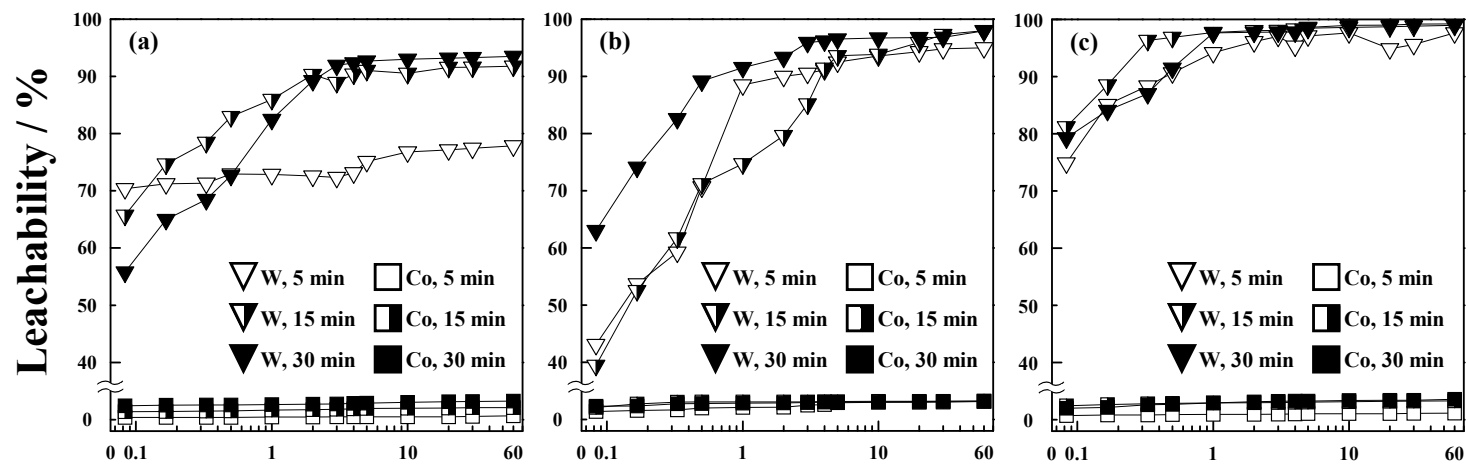

Leaching time / min

Figure 7. Effect of mixing ratio (soft scrap: $\mathrm{NaOH}$ ) and grinding duration on the dissolution of $\mathrm{W}$ and Co via water-leaching: (a) 1:0.3, (b) 1:0.4, and (c) 1:0.5 (pulp density: $10 \mathrm{~g} / \mathrm{L}$, room temperature, stirring speed: $400 \mathrm{rpm})$.

In summary, the leaching of $\mathrm{W}$ increased with increasing $\mathrm{NaOH}$ and increasing grinding time, and Co could not easily be extracted regardless of the conditions of grinding or leaching that were used. 


\section{Conclusions}

We developed a new process that involves a mechanochemical (MC) reaction which enables the recovery of tungsten with a high yield as well as the extraction of tungsten selectively from oxidized soft scrap by using only water as a leaching agent. Soft scrap was screened with a \#500 sieve, then subjected to oxidation, $\mathrm{MC}$ reaction, and water-leaching in turn to provide information and the optimal conditions to achieve effective recycling.

The oxidation of the soft scrap proceeded at $550{ }^{\circ} \mathrm{C}$ (for $1 \mathrm{~h}$ in air) to transform it into $\mathrm{WO}_{3}$ and $\mathrm{CoWO}_{4}$ (according to TG and XRD analysis). It was essential for the scrap to be treated at $600{ }^{\circ} \mathrm{C}$ to eliminate unreacted WC.

Sodium tungsten oxide $\left(\mathrm{Na}_{2} \mathrm{WO}_{4}\right)$ was synthesized through a solid-state $\mathrm{MC}$ reaction between oxidized scrap and $\mathrm{NaOH}$ with grinding under atmospheric conditions. The $\mathrm{MC}$ reaction proceeded as grinding progressed and was bolstered by the addition of $\mathrm{NaOH}$. With increasing $\mathrm{NaOH}, \mathrm{Na}_{2} \mathrm{CO}_{3}$ and $\mathrm{Na}_{2} \mathrm{WO}_{4}$ were synthesized after only $10 \mathrm{~min}$ of grinding. This progression had a critical effect on the subsequent room temperature water-leaching step.

The leachability of $\mathrm{W}$ in the ground mixture increased as the ratio of $\mathrm{NaOH}$ increased during the MC treatment. Consequently, $99.2 \%$ of $\mathrm{W}$ was extracted from the ground mixture of oxidized scrap by water-leaching for $60 \mathrm{~min}$ with a mixing ratio of 1:0.5 (scrap: $\mathrm{NaOH}$ ), while the extraction of $\mathrm{Co}$ was limited to $3.57 \%$ under the same conditions.

Acknowledgments: This study was supported by the R\&D Center for Valuable Recycling (Global-Top R\&BD Program) of the Ministry of Environment (Project No. 2016002230002). This work was also supported by Korea Energy and Mineral Resources Engineering Program funded by the Ministry of Trade, Industry and Energy.

Author Contributions: Jaeryeong Lee and Suyun Kim conceived and designed the experiments; Suyun Kim and Byoungin Kim performed the mechanochemical reaction experiments and analyzed the ICP, TG-DTA, and XRD data; Jaeryeong Lee wrote the paper and modified the paper; all authors contributed equally to the discussion.

Conflicts of Interest: The authors declare no conflict of interest.

\section{References}

1. Penrice, T.W. Alternative binders for hard metals. J. Mater. Shap. Technol. 1987, 5, 35-39. [CrossRef]

2. Ogwu, A.A.; Davies, T.J. Proposed selection rules for suitable binders in cemented hard metals with possible applications for improving ductility in intermetallics. J. Mater. Sci. 1992, 27, 5382-5388. [CrossRef]

3. Paul, R.L.; Te Riele, W.A.M.; Nicol, M.J. A novel process for recycling tungsten carbide scrap. Int. J. Miner. Process. 1985, 15, 41-56. [CrossRef]

4. Grzesik, W. Advanced Machining Processes of Metallic Materials: Theory, Modelling and Applications, 1st ed.; Elsevier: Oxford, UK, 2008.

5. Prakash, L.J. Application of fine grained tungsten carbide based cemented carbides. Int. J. Refract. Met. Hard Mater. 1995, 13, 257-264. [CrossRef]

6. Lee, D.J.; Yoo, C.S. Predicting a promising fusion technology in geoscience and mineral resources engineering using Korean patent data. Geosyst. Eng. 2014, 17, 34-42. [CrossRef]

7. Nakamura, T. E-Scrap recycling system and technologies in Japan. Geosyst. Eng. 2014, 17, 104-112. [CrossRef]

8. Shibata, J.; Murayama, N.; Niinae, M. Recovery of tungsten and cobalt from tungsten carbide tool waste by hydrometallurgical method. Geosyst. Eng. 2014, 17, 120-124. [CrossRef]

9. Han, K.N.; Kellar, J.J.; Cross, W.M.; Safarzadeh, S. Opportunities and challenges for treating rare-earth elements. Geosyst. Eng. 2014, 17, 178-194. [CrossRef]

10. Kim, J.R.; Song, Y.E.; Munussami, G.; Kim, C.M.; Jeon, B.H. Recent applications of bio electrochemical system for useful resource recovery: Retrieval of nutrient and metal from wastewater. Geosyst. Eng. 2015, 18, 173-180. [CrossRef]

11. Lee, J.R.; Lee, J.W.; Kim, B.J.; Kim, Y.J. Leaching behavior of Al, Co and W from the Al-alloying treated WC-Co tool as a new recycling process for WC hard scrap. Metals 2016, 6, 174. [CrossRef]

12. Walraedt, J. The coldstream process: A new powder production equipment. Powder Metall. Int. 1970, 3, $24-27$. 
13. Barnard, P.G.; Heine, K. Reclamation of Refractory Carbides from Carbide Materials. U.S. Patent 3,595,484, 27 July 1971.

14. Edward, M.T. Process of Separating Hard Constituents from Sintered Hard Metals. U.S. Patent 2,407,752, 17 September 1946.

15. Kojima, T.; Shimizu, T.; Sasai, R.; Itoh, H. Recycling process of WC-Co cermets by hydrothermal treatment. J. Mater. Sci. 2005, 40, 5167-5172. [CrossRef]

16. Malyshev, V.V.; Gab, A.I. Resource-saving methods for recycling waste tungsten carbide-cobalt cermets and extraction of tungsten from tungsten concentrates. Theor. Found. Chem. Eng. 2007, 41, 436-441. [CrossRef]

17. Ghandehari, M.H.; Faulkner, J.K.; Schussler, M. Selective dissolution of the binder phase alloy (Co-W) from WC-Co cemented carbides in particulate bed electrode systems. J. Electrochem. Soc. 1982, 129, 2666-2668. [CrossRef]

18. Brookes, K.J.A. Reclaimed tungsten powders with 'virgin' properties. Met. Powder Rep. 1990, 45, 131-132. [CrossRef]

19. Venkateswaran, S.; Schubert, W.D.; Lux, B.; Ostermann, M.; Kieffer, B. W-scrap recycling by the melt bath technique. Int. J. Refract. Met. Hard Mater. 1996, 14, 263-270. [CrossRef]

20. Gu, W.H.; Jeong, Y.S.; Kim, K.M.; Kim, J.C.; Son, S.H.; Kim, S.J. Thermal oxidation behavior of WC-Co hard metal machining tool tip scraps. J. Mater. Process. Technol. 2012, 212, 1250-1256. [CrossRef]

(c) 2017 by the authors. Licensee MDPI, Basel, Switzerland. This article is an open access article distributed under the terms and conditions of the Creative Commons Attribution (CC BY) license (http://creativecommons.org/licenses/by/4.0/). 